Research Journal of Poultry Sciences 4 (2): 22-27, 2011

ISSN: $1993-5285$

(C) Medwell Journals, 2011

\title{
Effects of Feeding Onion (Allium cepa) and Garlic (Allium sativum) on Some Performance Characteristics of Broiler Chickens
}

\author{
Slyranda Baltini Aji, Kennedy Ignatius, Asha'Adatu Y. Ado, Joel Bakari Nuhu, Auwal Abdulkarim, \\ Usman Aliyu, Muhammad Bello Gambo, Mohammed Adamu Ibrahim, Haruna Abubakar, \\ Mohammed M. Bukar, Hama'Adama M. Imam and Patrick T. Numan \\ Department of Animal Health and Production Technology, \\ Adamawa State College of Agriculture, Ganye, Nigeria
}

\begin{abstract}
In view of the current shift towards the use of growth promoters of natural origin, this study was carried out to determine the effects of feeding onion and garlic on some performance characteristics (body weight, feed intake, water intake, feed conversion ratio, feeding cost and carcass yield) of broiler chickens. A total of 104,4 weeks old broiler chickens were divided into 2 equal groups of 62 birds each at random (one for onion and the other for garlic) and used in the study. The result of the study revealed that garlic and onion significantly $(\mathrm{p}<0.05)$ increased the body weight of birds at 50 and $100 \mathrm{mg}$ dose whereas only $100 \mathrm{mg}$ of onion significantly $(\mathrm{p}<0.05)$ increased their feed and water intake. There was improvement in the feed conversion ratio of all the treated birds but those of the group that were given onion appeared better. The study also revealed that onion at 25 and $50 \mathrm{mg}$ decreased the feeding cost of the treated group of birds at the end of the 21 days trial period but at $100 \mathrm{mg}$ and garlic at all the doses regimens used increased their feeding cost. Both treatments did not affect the carcass yield of the birds. It was concluded that onion and garlic could be used to improve the productive performance of broiler chickens but more studies need be done to establish the appropriate amount, age and other favorable conditions under which the best result can be achieved with these plant materials.
\end{abstract}

Key words: Onion, Allium cepa, garlic, Allium sativum, broiler chickens, performance characteristics

\section{INRODUCTION}

Supplementing animal feeds with antibiotic-based growth promoters has been common practice for many years (Wegener et al., 1999). It helps growing animals to efficiently digest their food, derive maximum benefit from it and thereby allowing them to grow as strong and healthy individuals. Among the common antibiotics used as growth promoters in livestock animals are virginamycin, salinomycin, neomycin, doxycycline and avilamycin, etc. (Kumar et al., 2010).

The use of antibiotic-based growth promoters is presently facing serious criticism and has raised global concern as some reports revealed their ill effects among which are development of microbial resistance to the products and their potential harmful effects on human health (Rahmatnejad et al., 2009). These shortcomings lead to the search for alternative substances that eliminates these threats. Recently there is also an increasing interest in utilization of growth promoters of natural origin (Holden et al., 1998; Grela and Klebaniuk, 2007). Probiotics, prebiotics and medicinal plants as natural feed additives are currently used in poultry diets to enhance the performance and immune response of birds (Rahmatnejad et al., 2009).

Garlic (Allium sativum) and onion (Allium cepa) which belong to the family Liliaceae and the genus Allium (Ebesunun et al., 2007) are among the common medicinal plants used as growth promoters (Ali and Zahran, 2010). Garlic has several beneficial effects on both humans and animals having antimicrobial, antioxidant as well as antihypertensive properties (Sivam, 2001). These functions were attributed to bioactive components present in garlic (Amagase et al., 2001), one of which is a sulphur-containing organic compound known as diakyl polysufides which possess antimicrobial activity (Tsao and Yin, 2001) that could be responsible for the growth promoting effect of garlic. Onion is also a rich source of this substance (Kumar et al., 2010).

Corresponding Author: Slyranda Baltini Aji, Department of Animal Health and Production Technology, Adamawa State College of Agriculture, Ganye, Nigeria 
The objectives of this study is to determine and compare the effect of orally administered garlic and onion on some performance characteristics (body weight, feed intake, feed conversion ratio, feeding cost, water intake and carcass yield) of broiler chickens.

\section{MATERIALS AND METHODS}

Collection and preparation of plant materials: Fresh garlic (Allium sativum) and onions (Allium cepa) bulbs were purchased from Ganye market in Ganye local government Area of Adamawa state in Nigeria which lies between latitude $9^{\circ} 15^{\prime \prime} \mathrm{N}$ and longitude $12^{\circ} 17^{\prime \prime} \mathrm{E}$. They were peeled, grated into smaller pieces and air-dried. The dried garlic and onion were separately pulverized and stored in cellophane bags until required for use.

The experimental animals: A total of 104 apparently healthy day old broiler chicks of both sexes purchased from ECWA Livestock Production Farm, Jos, Plateau state of Nigeria were used for the research. They were housed in a newly constructed poultry house and were given clean water and commercially prepared feeds (Grand Feeds and Oil Mills, Ibadan, Nigeria) ad libitum. The birds were brooded for 3 weeks and allowed to adjust for another 1 week before the commencement of the experiment. All the required vaccinations were done.

Administration of plant material: The birds were randomly separated into 2 equal groups of 52 birds each labeled group 1 and 2. Birds in each group were further subdivided into 4 subgroups of 13 birds each and labeled subgroups $1 \mathrm{~A}, 1 \mathrm{~B}, 1 \mathrm{C}$ and $1 \mathrm{D}$ and $2 \mathrm{~A}, 2 \mathrm{~B}, 2 \mathrm{C}$ and $2 \mathrm{D}$. Birds in subgroups $1 \mathrm{~B}, 1 \mathrm{C}$ and $1 \mathrm{D}$ were daily given orally 25,50 and $100 \mathrm{mg}$, respectively of dissolved onion powder for 21 days while those in subgroup $1 \mathrm{~A}$ served as control. Similarly, birds in subgroups $2 \mathrm{~B}, 2 \mathrm{C}$ and $2 \mathrm{D}$ were given daily, 25,50 and $100 \mathrm{mg}$, respectively of dissolved garlic powder for 21 days while those in subgroup $2 \mathrm{~A}$ served as control.

Determination of body weight: The body weight of the birds was determined on the 1 st day of extract administration and was repeated weekly up to the last day of the experiment.

Determination of feed intake: Daily feed intake of the birds was determined by weighing the amount of feed given to each subgroup in the morning and subtracting the weight of the remaining feed the next morning from the initial weight to get the amount of feed consumed.
Determination of feed conversion ratio: The feed conversion ratio was determined using the methods of Contreras-Castillo et al. (2008) by dividing the feed intake by the body weight gained.

Determination of feeding cost: The feeding cost per each subgroup was determined by calculating the total weight of the feed consumed and determining the cost from the cost price per $\mathrm{kg}$ of feed as obtained from the cost price per bag $(25 \mathrm{~kg}$ ) of feed (i.e., $2,150.00 \mathrm{~K}$ ).

Determination of water intake: Daily water intake for each subgroup was determined by measuring the amount of water given in the morning and determining its differences with the remaining amount of water the next morning.

Determination of carcass yield: All the birds were slaughtered on the last day of the experiment. They were defeathered, eviscerated and dressed. Their dressed weight were determined and compared with their live weight in and the difference was used to calculate their percentage carcass yield.

Statistical analysis and presentation of results: Data obtained from the study were analyzed using computer software (GraphPad InStat, version 3.10, 32 bit for Windows, 2009 by GraphPad Software Inc.). Results were presented as Mean \pm SD and differences between Means were determined using ANOVA. Level of significance between means were considered at $p<0.05$ using the test of Tukey. Feeding cost values were express in terms of Nigerian Naira ( $)$ and Kobo $(\mathrm{K})$ while carcass yields as simple percentages.

\section{RESULTS AND DISCUSSION}

The result of the study revealed that by day 7 , birds that received $100 \mathrm{mg}$ of onion and garlic showed significant $(p<0.05)$ increase in body weight compared to the control birds (Table 1), similarly by day 14-21 of treatment, birds that received 50 and $100 \mathrm{mg}$ of onion had their body weights significantly $(p<0.05)$ increased while only by day 21 was there significant $(p<0.05)$ increase in body weight of birds treated with $100 \mathrm{mg}$ of garlic. No significant $(p>0.05)$ variation in body weights were observed in birds treated with $25 \mathrm{mg}$ of both onion and garlic.

Daily treatment of birds with $100 \mathrm{mg}$ of onion significantly $(p<0.05)$ increased their feed intake 
Res. J.Poult. Sci., 4 (2): 22-27, 2011

Table 1: Body weight of broiler birds treated with onion and garlic Body weight in $\mathrm{kg}(\mathrm{Mean} \pm \mathrm{SD})$

Onion (days) Garlic (days)

\begin{tabular}{lcccccc} 
Group (n=13) & 7 & 14 & 21 & 7 & 14 & 21 \\
\hline A (Control) & $1.41 \pm 0.25$ & $1.67 \pm 0.29$ & $1.95 \pm 0.38$ & $1.25 \pm 0.25$ & $1.63 \pm 0.29$ & $2.04 \pm 0.29$ \\
B (25 mg) & $1.51 \pm 0.16$ & $1.81 \pm 0.14$ & $2.20 \pm 0.19$ & $1.51 \pm 0.10$ & $1.91 \pm 0.33$ & $2.15 \pm 0.21$ \\
C (50 mg) & $1.51 \pm 0.18$ & $1.99 \pm 0.19^{*}$ & $2.41 \pm 0.11^{*}$ & $1.51 \pm 0.17$ & $1.99 \pm 0.23$ & $2.37 \pm 0.17^{*}$ \\
D (100 mg) & $1.74 \pm 0.17^{*}$ & $2.29 \pm 0.14^{*}$ & $2.57 \pm 0.13^{*}$ & $1.69 \pm 0.19^{*}$ & $2.11 \pm 0.12^{*}$ & $2.65 \pm 0.09^{*}$ \\
\hline
\end{tabular}

*Value is significantly higher $(p<0.05)$ when compared with that of its control

Table 2: Effect of onion and garlic on the feed intake of broiler birds Feed intake in $\mathrm{kg}(\mathrm{Mean} \pm \mathrm{SD})$

\begin{tabular}{|c|c|c|c|c|c|c|}
\hline \multirow[b]{3}{*}{ Group ( $n=13)$} & \multicolumn{6}{|l|}{ Feed inake } \\
\hline & \multicolumn{3}{|c|}{ Onion (days) } & \multicolumn{3}{|c|}{ Garlic (days) } \\
\hline & 7 & 14 & 21 & 7 & 14 & 21 \\
\hline A (Control) & $1.05 \pm 0.10$ & $1.17 \pm 0.11$ & $1.13 \pm 0.08$ & $1.12 \pm 0.16$ & $1.08 \pm 0.11$ & $1.20 \pm 0.15$ \\
\hline B (25 mg) & $0.92 \pm 0.14$ & $1.09 \pm 0.13$ & $1.11 \pm 0.45$ & $1.42 \pm 0.41$ & $1.26 \pm 0.28$ & $1.28 \pm 0.17$ \\
\hline $\mathrm{C}(50 \mathrm{mg})$ & $1.05 \pm 0.05$ & $1.09 \pm 0.10$ & $1.16 \pm 0.08$ & $1.06 \pm 0.10$ & $1.19 \pm 0.63$ & $1.35 \pm 0.08$ \\
\hline $\mathrm{D}(100 \mathrm{mg})$ & $1.24 \pm 0.15^{*}$ & $1.26 \pm 0.07^{*}$ & $1.29 \pm 0.10^{*}$ & $1.20 \pm 0.23$ & $1.41 \pm 0.15$ & $1.46 \pm 0.12$ \\
\hline
\end{tabular}

*Value is significantly higher $(p<0.05)$ when compared with that of its control

Table 3: Effect of onion and garlic on the water intake of broilers birds Water intake in $\mathrm{L}(\mathrm{Mean} \pm \mathrm{SD})$

Onion (days) Garlic (days)

\begin{tabular}{lcccccc} 
Group (n=13) & 7 & 14 & 21 & 7 & 14 & 21 \\
\hline A (Control) & $1.92 \pm 0.40$ & $2.19 \pm 0.29$ & $2.41 \pm 0.39$ & $2.21 \pm 0.29$ & $2.24 \pm 0.32$ & $2.42 \pm 0.51$ \\
B ( $25 \mathrm{mg})$ & $1.75 \pm 0.16$ & $2.13 \pm 0.21$ & $2.39 \pm 0.21$ & $2.53 \pm 0.28$ & $2.42 \pm 0.39$ & $2.70 \pm 0.39$ \\
C (50 mg) & $1.91 \pm 0.25$ & $2.09 \pm 0.10$ & $2.51 \pm 0.29$ & $2.19 \pm 0.45$ & $2.10 \pm 0.31$ & $2.46 \pm 0.51$ \\
D (100 mg) & $2.50 \pm 0.15^{*}$ & $2.52 \pm 0.25^{*}$ & $2.88 \pm 0.19^{*}$ & $2.17 \pm 0.27$ & $2.48 \pm 0.29$ & $2.57 \pm 0.56$ \\
\hline
\end{tabular}

*Value is significantly higher $(p<0.05)$ when compared with that of its control

throughout the 3 weeks trial period (Table 2). At all the dose regimens used, garlic did not significantly $(\mathrm{p}>0.05)$ affect the feed intake of birds when compared with the control group of birds. Similar results were obtained for onion at 25 and $50 \mathrm{mg}$ dose.

The result of the effect of treatment of birds with onion and garlic on their water intake is shown in Table 3. Birds that received 25 and $50 \mathrm{mg}$ of onion did not show any significant $(p>0.05)$ variation in their water intake. Similar result were obtained with all the dose regimens for garlic however, treatment with $100 \mathrm{mg}$ of onion significantly $(\mathrm{p}<0.05)$ increased the bird's water intake throughout the 3 weeks trial period.

A trend of decreasing values of feed conversion ratio of birds treated with onion and garlic was observed (Table 4). Treatment with 25,50 and $100 \mathrm{mg}$ of onion produced a remarkably appreciable decrease in the values of feed conversion ratio of the birds when compared with their controls. Similar results were obtained with treatment with 50 and $100 \mathrm{mg}$ of garlic. Treatment with $25 \mathrm{mg}$ of garlic did not produce any change in the feed conversion ratio of birds.
Table 4: Feed conversion ratio of broiler birds orally treated with onion and garlic

\begin{tabular}{|c|c|c|c|c|c|c|}
\hline \multirow{4}{*}{$\begin{array}{l}\text { Group } \\
(n=13)\end{array}$} & \multicolumn{6}{|c|}{ Feed conversion ratio ( $\mathrm{kg}: \mathrm{kg}$ ) } \\
\hline & \multicolumn{3}{|c|}{ Onion (days) } & \multicolumn{3}{|c|}{ Garlic (days) } \\
\hline & \multirow{2}{*}{7} & \multirow{2}{*}{14} & \multirow{2}{*}{21} & \multirow[t]{2}{*}{---} & \multirow[b]{2}{*}{14} & \multirow{2}{*}{21} \\
\hline & & & & & & \\
\hline A (Control) & 0.74 & 0.70 & 0.58 & 0.90 & 0.66 & 0.59 \\
\hline $\mathrm{B}(25 \mathrm{mg})$ & 0.61 & 0.60 & 0.50 & 0.94 & 0.66 & 0.60 \\
\hline $\mathrm{C}(50 \mathrm{mg})$ & 0.70 & 0.55 & 0.48 & 0.70 & 0.60 & 0.57 \\
\hline $\mathrm{D}(100 \mathrm{mg})$ & 0.71 & 0.55 & 0.50 & 0.71 & 0.67 & 0.55 \\
\hline
\end{tabular}

Treatment of birds with $100 \mathrm{mg}$ of onion caused an increase in the feeding cost of the birds when compared with the control birds whereas treatment with 25 and $50 \mathrm{mg}$ of onion reduced their feeding cost (Table 5). Garlic at all the dose regimens used in the experiment caused an increase in the cost of feeding of the birds when compared with those of the control birds.

There were no significant differences in the carcass yield of all the treatment groups of both onion and garlic when compared with there respective control birds (Table 6).

Treatment of birds with onion and garlic at of $25 \mathrm{mg}$ for 21 days did not produce any significant $(\mathrm{p}>0.05)$ change in either group of birds. This may be due to the 
Res. J.Poult. Sci., 4 (2): 22-27, 2011

Table 5: Feeding cost of broiler birds treated with onion and garlic

Cost of feeding in Naiora and Kobo ( $\mathrm{N}$ and $\mathrm{K}$ )

Onion (days) Garlic (days)

\begin{tabular}{|c|c|c|c|c|c|c|c|c|}
\hline \multirow[b]{2}{*}{ Group $(n=13)$} & & \\
\hline & 7 & 14 & 21 & Subgroup total & 7 & 14 & 21 & Subgroup total \\
\hline A (Control) & 90.30 & 100.62 & 97.18 & $3,745.30$ & 96.32 & 92.88 & 103.20 & $3,801.20$ \\
\hline $\mathrm{B}(25 \mathrm{mg})$ & 79.12 & 93.74 & 95.46 & $3,488.16$ & 122.12 & 108.36 & 110.08 & $4,427.28$ \\
\hline $\mathrm{C}(50 \mathrm{mg})$ & 90.30 & 93.74 & 99.76 & $3,689.40$ & 91.16 & 102.34 & 116.10 & $4,024.80$ \\
\hline $\mathrm{C}(100 \mathrm{mg})$ & 106.63 & 108.36 & 110.94 & $4,237.09$ & 103.20 & 121.26 & 125.56 & $4,550.26$ \\
\hline Total & - & - & - & $11,414.65$ & - & - & - & $13,002.34$ \\
\hline
\end{tabular}

Table 6: Effect of feeding onion and garlic on the carcass yield of broiler bird Groups

\begin{tabular}{lllll} 
Treatments & A (Control) & B $(25 \mathrm{mg})$ & $\mathrm{C}(50 \mathrm{mg})$ & $\mathrm{D}(100 \mathrm{mg})$ \\
\hline Onion & & & & \\
LW (kg) & $1.95 \pm 0.38$ & $2.20 \pm 0.19$ & $2.41 \pm 0.11$ & $2.57 \pm 0.13$ \\
DW (kg) & $1.39 \pm 0.27$ & $1.53 \pm 0.15$ & $1.69 \pm 0.10$ & $1.83 \pm 0.16$ \\
CY (\%) & 71.28 & 69.55 & 70.12 & 71.20 \\
Garlic & & & & \\
LW (kg) & $2.04 \pm 0.29$ & $2.15 \pm 0.21$ & $2.37 \pm 0.17$ & $2.65 \pm 0.09$ \\
DW (kg) & $1.43 \pm 0.23$ & $1.51 \pm 0.26$ & $1.66 \pm 0.20$ & $1.85 \pm 0.11$ \\
CY (\%) & 70.10 & 70.23 & 70.04 & 69.81 \\
\hline
\end{tabular}

LW: Live Weight $($ Mean \pm SD); DW: Dressed Weight $($ Mean \pm SD); CY:

Percentage Carcass Yield

ineffectiveness of these low doses to produce any observable effect. Treatment of birds with $50 \mathrm{mg}$ of onion increased their body weight by day 14-21 while only by day 21 was increase in body weight observed in birds treated with $50 \mathrm{mg}$ of garlic. At $100 \mathrm{mg}$ however, both onion and garlic produced significant $(\mathrm{p}<0.05)$ increase in body weight of the birds throughout the period of the treatment. The highest dose $(100 \mathrm{mg})$ of onions produced significant $(\mathrm{p}<0.05)$ increase in the feed and water intake of birds whereas onion at 25 and $50 \mathrm{mg}$ and garlic at all the dose regimens used in the experiment did not affect the feed and water intake of the birds. This increase in water intake of the birds may be as a result of the direct consequence of increase in their feed intake. The result of this study also revealed a gradual improvement in the feed conversion ratio in the group of birds treated with onion and garlic although, those of birds treated with onions appeared to be better.

While there are scanty reports of research studies on the effect of onions on the productive performance of chickens and other livestock, reports on similar studies with garlic abound however, the results of these reports remain equivocal. For example, Rahmatnejad et al. (2009) reported that garlic given at $1000 \mathrm{~g} \mathrm{ton}^{-1}$ did not affect feed intake, weight gain and feed conversion ratio in broiler chickens. Javandel et al. (2008) reported that administration of garlic to broiler meal at $0.125,0.25,0.5,1$ and $2 \%$ did not result in any significant increase in their body weight gain instead at $2 \%$, it decreased their body weight while the lower doses $(0.125$ and $0.25 \%)$ increased feed intake. Similarly in a study by Ashayerizadeh et al.
(2009), they reported that garlic powder given at $1000 \mathrm{~g} \mathrm{ton}^{-1}$ for 42 days to broiler birds did not produce any significant effect on their body weight gain and feed conversion ratio. Ghasemi et al. (2010) also reported that the inclusion of 0.1 and $0.2 \%$ of garlic and thyme in layers feed did not significantly affect their body weight and feed conversion ratio.

Studies with results that differ somewhat from those above included those of Rahardja et al. (2010) who reported that at 1,2 and $4 \%$ levels in feed, garlic increased feed intake in a 4 weeks trial in laying hens. They also reported that these treatments increased the water intake of older chickens but that of younger birds remained unaffected. Kumar et al. (2010) reported that a garlic active based growth promoter given at $250 \mathrm{ppm}$ significantly increased the body weight of broilers chickens by day 42 of trial. Similarly, increased feed intake, body weight and feed conversion efficiency and a decrease in feeding cost with garlic supplementation at $250 \mathrm{mg} \mathrm{kg}^{-1}$ body weight have been reported in a 2 months trial in new born calves up to their 2 months pre-ruminant stage (Ghosh et al., 2010). Furthermore, increased weight gain and feed intake were observed in laying hens given garlic supplement but their feed conversion efficiency was not affected (Khan et al., 2007). In contrast to the above reports, Nidaullah et al. (2010) reported a reduction in the feed intake of broiler birds fed garlic supplement. Similarly, the inclusion of 0.1 and $0.2 \%$ garlic and thyme in layers' meal significantly decreased their feed intake by the 6th week (Ghasemi et al., 2010). Cullen et al. (2005) also reported a reduction in feed intake in pigs fed 1 and $10 \mathrm{~g} \mathrm{~kg}^{-1}$ garlic diet during their grower period.

It could be observed that the amounts of garlic used in most of the studies reported above were in percentages of feed or similar other forms that are higher than those used in this study. The choice for the low dose of onion and garlic used in this experiment was for the fact that garlic was reported to cause hemolytic anemia at $4 \%$ level in feed (Oboh, 2004) while onion given at 5, 10, 14, 20 and $25 \%$ of meal caused hemolytic anemia, decreased packed cell volume, hemoglobin concentration and red blood cell 
count. Therefore, avoiding these ill effects could as well make chance for better results with the use of these plant materials.

This study also revealed that treatment of birds with 25 and $50 \mathrm{mg}$ of onion caused a reduction in their feeding cost. This finding is of great significance since the importance of minimizing feeding cost in poultry production cannot be overemphasized. According to Ashayerizadeh et al. (2009), feed is a major segment of production in poultry industry thus efforts are usually made in poultry industry to increase the efficiency of feed utilization to minimize per unit cost of production. Conversely, $100 \mathrm{mg}$ of onion increased the feeding cost of the birds. This could be the direct consequence of the increased feed intake observed with feeding of onion at this dose level. Treatment of birds with garlic at all the dose regimens also caused an increase in the feeding cost of the birds when compared to the control birds, the highest increase being that with $100 \mathrm{mg}$ of garlic.

The result of this study also shows that the carcass yields of the broiler birds were not affected by any of the treatments with onion or garlic. Similar results were reported for feeding garlic at 1 and $10 \mathrm{~g} \mathrm{~kg}^{-1}$ to pigs (Cullen et al., 2005) and supplementation of feeds of broiler birds with antibiotics and probiotics (Contreras-Castillo et al., 2008). This result however, disagreed with those of Rahmatnejad et al. (2009) who reported that treatment of birds with garlic at $1000 \mathrm{~g} \mathrm{ton}^{-1}$ increased the percentage of their carcass yield in a 42 days trial and Ashayerizadeh et al. (2009) who reported a high percentage of carcass yield with low abdominal fats for broiler birds fed garlic and black cumin seeds.

Differences in experimental design, dose regimens, age of birds, concentration of constituents of plant materials, among other factors may account for the variation among the results above.

\section{CONCLUSION}

Researchers therefore, conclude that onion and garlic could be used to improve the performance of broiler chickens however, more studies need to be done to establish the appropriate amount, age and other favorable conditions under which the best result can be achieved with these plant materials.

\section{REFERENCES}

Ali, F.H. and D.A. Zahran, 2010. Effect of growth enhancers on quality of chicken meat during cold storage. Adv. J. Food Sci. Technol., 2: 219-226.
Amagase, H., B.L. Petesch, H. Matsuura, S. Kasuga and $\mathrm{Y}$. Itakura, 2001. Intake of garlic and its bioactive components. J. Nutr., 131: 955S-962S.

Ashayerizadeh, A., B. Dastar, E. Rahmatnejad, M.S. Shargh, O. Ashayerizadeh and S.M.R. Hossaini, 2009. Use of garlic (Allium sativum), black cumin seeds (Nigella sativa L.) and wild mint (Mentha longifolia) in broiler chickens diets. J. Anim. Vet. Adv., 8: 1860-1863.

Contreras-Castillo, C.J., C. Brossi, T.C. Previero and L.C. Dematte, 2008. Performance and carcass quality of broilers supplemented with antibiotics or probiotics. Brazilian J. Poult. Sci., 10: 227-232.

Cullen, S.P., F.J. Monahan, J.J. Callan and J.V.O. Doherty, 2005. The effect of dietary garlic and rosemary on grower-finisher pig performance and sensory characteristics of pork. Irish J. Agric. Food Res., 44: 57-67.

Ebesunun, M.O., O.O. Popoola, E.O. Agbedana, J.M. Olisekodiaka, J.A. Onuegbu and A.A. Onyeagala, 2007. The effect of garlic on plasma lipids and lipoproteins in rats fed on high cholesterol enriched diet. Biokemistri, 19: 53-58.

Ghasemi, R., M. Zarei and M. Torki, 2010. Adding medicinal herbs including garlic (Allium sativum) and thyme (Thymus vulgaris) to diet of laying hens and evaluating productive performance and egg quality characteristics. Am. J. Anim. Vet. Sci., 5: 151-154.

Ghosh, S., R.K. Mehla, S.K. Sirohi and B. Roy, 2010. The effect of dietary garlic supplementation on body weight gain, feed intake, feed conversion efficiency, faecal score, faecal coliform count and feeding cost in crossbred dairy calves. Trop. Anim. Health Prod., 42: $961-968$

Grela, E.R. and R. Klebaniuk, 2007. Chemical composition of garlic preparation and its utilization in piglet diets. Medycyna Wet, 63: 792-795.

Holden, P.J., J. Mckean and E. Franzenburg, 1998. Biotechnical for pigs-garlic (ASLR1559). ISU Swine Research Report, Iowa State University, Ames.

Javandel, F., B. Navidshad, J. Seifdavati, G.H. Pourrahimi and S. Baniyaghoub, 2008. The favorite dosage of garlic meal as a feed additive in broiler chickens ratios. Pak. J. Biol. Sci., 11: 1746-1749.

Khan, S.H., S. Rozina and A.M. Ashraf, 2007. Effects of dietary garlic on performance and serum and egg yolk cholesterol concentration in laying hens. Asian J. Poult. Sci., 1: 22-27.

Kumar, S., K.C. Sharadamma and P.M. Radhakrishna, 2010. Effects of a garlic active based growth promoter on growth performance and specific pathogenic intestinal microbial counts of broiler chicks. Int. J. Poult. Sci., 9: 244-246. 
Nidaullah, H., F.R. Durrani, S. Ahmad, I.U. Jan and S. Gul, 2010. Aqueous extract from different medicinal plants as anticoccidial, growth promotive and immunostimulant in broilers. ARPN J. Agricult. Biol. Sci., 5: 53-59.

Oboh, G., 2004. Prevention of garlic-induced hemolytic anemia using some tropical green leafy vegetables. J. Med. Food., 7: 498-501.

Rahardja, D.P., M.R. Hakim, W. Pakiding and V.S. Lestari, 2010. Hypocholesterolemic effect of garlic powder in laying hen: Low cholesterol egg? J. Indonesian Trop. Anim. Agric., 35: 16-21.

Rahmatnejad, E., H. Roshanfekr, O. Ashayerizadeh, M. Mamooee and A. Ashayerizadeh, 2009. Evaluation the effect of several non-antibiotic additives on growth performance of broiler chickens. J. Anim. Vet. Adv., 8: 1670-1673.
Rahmatnejad, E., H. Roshanfekr, O. Ashayerizadeh, M. Mamooee and A. Ashayerizadeh, 2009. Evaluation the effect of several non-antibiotic additives on growth performance of broiler chickens. J. Anim. Vet. Adv., 8: 1670-1673.

Sivam, G.P., 2001. Protection against Helicobacter pylori and other bacterial infections by garlic. J. Nutr., 131: 1106S-1108S

Tsao, S.M. and M.C. Yin, 2001. In vitro antimicrobial activity of four diallyl sulphides occurring naturally in garlic and Chinese leek oils. J. Med. Microbiol., 50: 646-649.

Wegener, H.C., F.M. Aarestrup, P. Gerner-Smidt and F. Bager, 1999. Transfer of antibiotic resistant bacteria from animals to man. Acta Veterinaria Scandinavica, 92: 51-57. 